Génopôle and for society at large," he says.

Support for a role for Genset comes from Eric Molinie, an official at the French Muscular Dystrophy Association. The charity has invested more than FF1 billion in the Evry Génopôle and was the largest funder of French genome research before it shifted its focus in the mid-1990s to gene therapy.

The consortium proposal is "a good way to unite public and private genome research", says Molinie, arguing that that there are few genome companies in Europe with the size and expertise of Genset. The consortium would allow France to recapture the lead it has lost in genomics, he says.

But Charles Auffray, a leading French genome researcher, says that - while there is a clear need to relaunch genome research in France - he prefers an integrated approach that would assemble a broad spectrum of public and private bodies within a comprehensive pre-competitive programme. Discussions on the way forward need to be more open, says Auffray.

The need for a broad approach is also supported by Bernard Pau, director of biotechnology policy at the Centre National de la Recherche Scientifique, and a member of a panel set up by the government to recommend a new national strategy for life sciences (see previous page).

Pau argues that genome research itself is increasingly seen as being less important than post-genome research areas. This view seems to be shared by the markets.

Genomics is now considered to be a "lowprice commodity", says Genghis LloydHarris, director of equity research for the pharmaceutical and biotechnology sectors at the investment bank, Credit Suisse First Boston.

"The market is more interested in postgenome research, such as proteomics and DNA chip technology, which it sees as being more directly related to drug discovery," says Lloyd-Harris.

Such reasoning is one explanation for market dissatisfaction with Genset. A more immediate cause for the fall in its shares, suggests Ernie Knewitz, from Noonan-Russo Communications - Genset's public relations firm - is the recent decision by ten of the world's leading pharmaceutical companies and Britain's Wellcome Trust to fund a US\$45-million map of the variations in the human genetic code linked to common diseases (see Nature 398, 545; 1999).

By agreeing not to patent the map and to make it freely available, the group has implicitly challenged Genset's core business, namely mapping such single-nucleotide polymorphisms (SNPs) and striking alliances with pharmaceutical companies. One industry analyst says the new initiative turns SNP mapping into "pre-competitive research".

Knewitz points out that Michael King, an analyst at Robertson Stevens, has reiterated the firm's "buy rating" on Genset, in the belief that the company has a large head start on the consortium and should complete its own proprietary map by the end of the year. "Investor concerns have been overplayed," says the text accompanying the rating. "The high level of interest in SNPs validates the Genset approach.”

But one analyst expresses concern that Genset failed to live up to its "emphatic promises on milestones in terms of the number of SNPs mapped. The market was angry in feeling that it was misled."

Brandys vehemently denies this, arguing that numbers of SNPs or progress in mapping are irrelevant. The wider system for gene discovery is what counts, he says, including large-scale genotyping and analytical methods. "We have always been prudent in our claims," he asserts. "All that counts is our portfolio of patents. Our only milestone is gene discovery."

But the analyst adds that Genset pales besides rivals such as Celera, set up by genome pioneer Craig Venter, "which has patented thousands of genes and has three of its own products in clinical trials".

The market response to any new government support for Genset is unpredictable. "We are working on the assumption that Genset will get a whole lot of money," says one analyst.

DeclanButler

\title{
Increase in German science budget a boon for women and youth
}

[MUNICH] Germany's coalition government, which made a pre-election promise to double research spending within five years, has approved an 11 per cent rise in the 1999 science budget.

The increase brings the science budget to nearly DM15 billion (US $\$ 8.2$ billion). The new money will be primarily used to support research in biotechnology and information sciences (see Nature 398, 7; 1999). In biotechnology and molecular medicine, for example, an additional DM233 million will be made available in project money, and a new programme on the plant genome will belaunched.

It will also be used to secure Germany's future scientific base by improving career prospects for young scientists and women. For example, it will pay for a new postgraduate programme, the Emmy Noether programme - named after a famous German female mathematician - launched this year by the Deutsche Forschungsgemeinschaft (DFG), Germany's university grant-making agency.

The programme supports young scientists, who must be under 30 when they apply, to complete two years of research abroad and then return to Germany to set up a university research group. The group's operating costs will be covered for three years. Normally, German scientists are well into their forties before

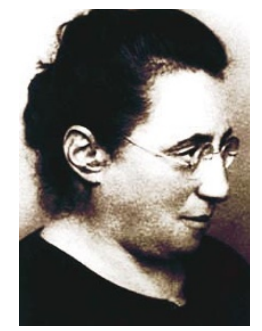

Noether: inspires a new programme. they have the opportunity to direct their own research group.

The Emmy Noether programme has been allocated DM14 million for the current year, but this will rise to DM60 million a year as the number of researchers supported grows.

The extra money will also be used to launch a DM7.5 million programme of special measures to promote women's career prospects. These include special coaching programmes for women identified as talented during postdoctoral work.

These coaching programmes will be designed to "prepare women for competition for senior posts - particularly in strongly male-dominated areas like information science - before they disappear from science for ever", says a ministry spokeswoman.

But she points out that measures to promote equality of opportunity for women are not "ghettoized" in this new programme — all ministry programmes will be regularly audited to assess efforts to promote equality. "The spirit pervades the whole ministry," she says.

The same spirit will permeate most of
Germany's research organizations. For example, the DFG's Emmy Noether awards can be used in part to pay for child care. Recipients may choose to work part-time for an extended period to allow them to build a family.

Moreover, in plans drawn up between the ministry and the Helmholtz Society (the umbrella group of Germany's 16 large national research centres), the society has pledged to promote 100 women to top positions in its research centres in the next few years. The Research Centre Jülich has already started an active recruiting campaign (see Nature 398, $550 ; 1999)$.

Other measures include support of an International Women's University that will be established for 100 days during next summer's EXPO in Hanover. One thousand women from around the world will attend the university to teach and carry out research on seven themes: the city, work, migration, the body, intelligence, the information society, and water.

The ministry's new money also increases by DM200 million the federal government's contribution to university building and large equipment, which has been capped at DM1.8 billion for years. Germany's Science Council, the Wissenschaftsrat, has long complained that the building programme was dangerously underfunded.

Alison Abbott 